\title{
Future Studies of Virtual State Formation in Iran and Its Effect on the Promotion of Global Peace Index (the Outlook of 1404)
}

\author{
Mandana Sajjadi ${ }^{1}$ \\ ${ }^{1}$ Allameh Tabataba'i University, Faculty of Low and Political Sciences, Tehran, Iran \\ Correspondence: Mandana Sajjadi, Allameh Tabataba'i University, Faculty of Low and Political Sciences, Tehran, \\ Iran. E-mail: sajjadiatu@gmail.com
}

Received: February 14, 2016

Accepted: March 8, 2016 Online Published: March 31, 2016

doi:10.5539/jpl.v9n2p200

URL: http://dx.doi.org/10.5539/jpl.v9n2p200

\begin{abstract}
In this study, it has been attempted to investigate the feasible and desirable futures regarding the possibility of virtualization of Islamic Republic of Iran's state and its effect on the promotion of Global Peace Index (GPI) using trend analysis technique, Delphi surveys and scenario building .Therefore, according to the documents such as perspective and development documents, the outlook of $1404 \mathrm{SH}$ has been considered as a time period of desirable future formation. The writer believes that the formation of virtual state in Iran through decreasing structural violence in society leads to the promotion of GPI. In fact, the dynamics of new global arrangements that have been derived from the technological innovations and socioeconomic adjustments of international relations actors with agencies and global markets, have led to the formation of a new pattern for the conceptualization of states's evolving nature, that in turn, can increase the possibility of positive peace elements through decreasing the level of structural violence in society. In order to confirm this assumption, seven key deriving forces of virtual states have been chosen referring the systematic theory of virtual state by Richard rosecranace and combining it with Galtung's positive peace theory and their evolution has been investigated since writing the outlook documents. On the next step, four main scenarios were formed in response to the probability of virtual state formation around two axes of states' commitments to pursue open economic policies and sanctions lifting as two independent variables. Finally, all four scenarios were evaluated using Delphi surveys of elites and one scenario was chosen as the probable future.
\end{abstract}

Keywords: future studies, global peace index, virtual state, Delphi survey, interdependence

\section{General Terms}

\subsection{Problem}

The establishment of peace in the world, as the most important collective necessity, has been considered as the most fundamental human desire and the main concern of political science and international relations scientists. But undoubtedly, the First World War led to the increased attentions toward peace and after the Second World War in 1950s, with the establishment of Center for Advanced Study in the Behavioral Sciences at Stanford University, this issue became one of the academic discussions of the world. From the very first beginning, many scientists attempted to measure this phenomenon in a careful way. Finally, these commitments led to the underpinning of Global Peace Index (GPI).

Nowadays, with the growth of knowledge and complex social relationships, the importance of peace studies is needed more than ever. On the other hand, with stepping into the third industrial revolution of the world, unprecedented development of communication and information technologies, most of the previous concepts and definitions of international relationships have been changed and liberal scientists, in accordance with these developments, are following the probability of access to a modern method. The dynamics of modern global arrangements that are originated from the innovations of technology and socioeconomic accordance of international relationship actors with global markets and agencies, have led to the evolution of state as the main actor of international relationships.

In this regard, Richard Rosecrance, who is among the scientists of late-systematic school in international relationships as well as its more advanced alternative (i.e. interdependence), considers the emergence of modern form of state as a tool to reach world peace in today's changing world. According to him, in fact,the international 
system is shaping sustainable progress in accordance with peace and economic security. In this view, with the gradual limitation of purely national competences in favor of international competences as well as the transnational, some of the cases of structural violence will subside within the national and transnational communities.

The states that are reminded as virtual states by Rosecrance, unanimously have allocated appropriate ranks to themselves in the classification of GPI. For example, in the last classification (2014), Swiss, Japan and Taiwan are located within the ranks of 5, 8 and 28, respectively. In fact,those states that have perfect condition, are the most peaceful countries. However, Iran and most countries in the Middle East have been above 100.

On the other hand, it should not be ignored that economic development is subject to peace. Indeed, peace is related to indices such as income, education and regional uniformity and those countries that have gained the ability to promote GPI, indicate more flexibility regarding intra-system shocks and disputes. This flexibility refers to the capability of social systems for absorbing stress and self-restoration as well as a capacity regarding renewal and adaptation. The Islamic Republic of Iran as a country that has always announced peace as its main strategy and direction, has been located in a region in which the neighbors indicate high levels of violence. Due to the conceptual framework of the virtual state ,in the outlook of 1404, as the most important developmental document of the country, several propositions are there that indicate the tendency of the Islamic Republic of Iran toward activating virtualization procedures (20-year outlook, 2013). However, unfortunately, despite emphasizing the main developmental indices such as developing the sections of research and development, planning, direct instructional investment and attracting foreign investments on the fourth and fifth outlooks that all are necessary for the emergence of virtual state, Iran still has not made a positive step in order to improve its status in GPI ranking. It seems that the developmental documents have been somehow written based on an ideal manner and are far from the realities and capabilities of Iran's society. Therefore, the present study which concerns the future, regarding the intended time period of the document (i.e. outlook 1404) and using future studies methods such as Delphi surveys, is seeking to measure country's current distance and investigate the effect of this desired future on the promotion of 23 quantitative and qualitative indices of global peace.

\subsection{Research Questions}

Is there the possibility of forming virtual state in Iran by 1404? In the case of virtual state in Iran, how much this issue can affect the promotion of GPI?

\subsubsection{Secondary Questions}

1. What are dimensions and criteria of states' virtualization?

2. What are dimension and criteria of Global Peace Index (GPI)?

3. What kind of relationship exists between activating states' virtualization deriving and promotion of global peace?

4. What scenarios are imagined for the virtualization of Iran's state by the outlook of 1404 ?

5. Which of the scenarios are more probable regarding the future studies of state's virtualization and its effect on the promotion of global peace?

\subsection{Research Hypotheses}

Generally, in future studies, it is attempted to identify key variables or driving forces referring the previous theories and based on their current state, estimating their future state as various scenarios. Accordingly, first, in this study we attempt to identify driving forces and after investigating related trends as well as determining lack of fundamental uncertainties using Cross-Scenario approach, design four primary scenarios as the hypotheses of this study.

\subsection{Methodology}

Future studies based on trend analysis, scenario making, Delphi survey

Data collection method: library, online resources, Delphi interviews

The conceptual model of the employed methods in this study can be plotted as follow: 


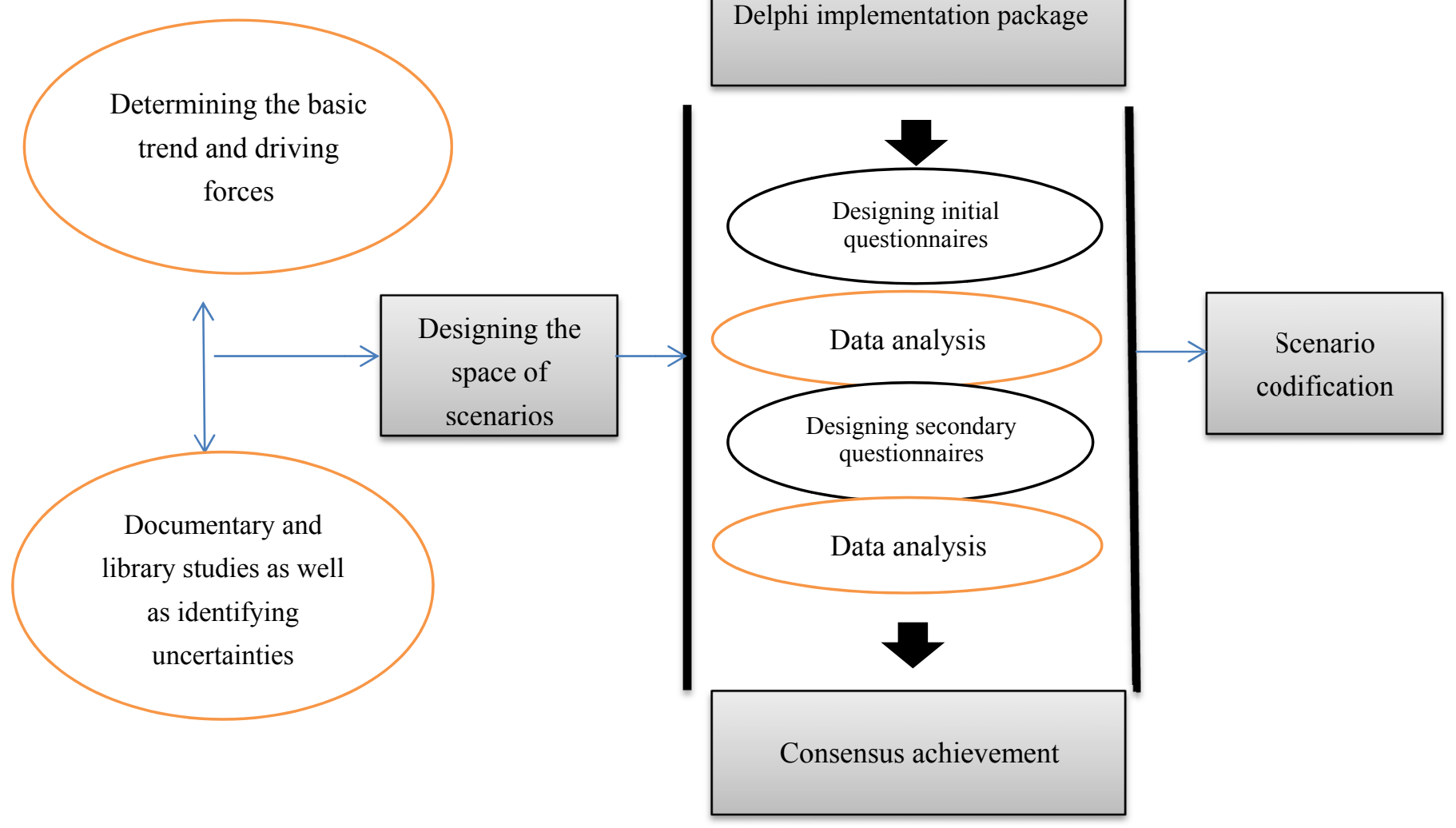

Figure 1.

The main goals of Delphi survey in this study are as follows:

- Extracting theories and experts' reckon preferences of economy, technology, international relationships, and peace regarding the possibility to achieve the outlook of 1404 based on the conceptual framework of virtual state

- Consensus-building regarding the effect of activating virtualization trends on the promotion of GPI

In order to determine the questions of Delphi survey, four basic questions were considered:

- In the case of sanctions lifting and the commitments by the Islamic Republic states for taking free and open economic policies, how much it is possible for Iran to become a combined virtual state by the outlook of 1404 ? If so, what would be the state of GPI?

- In the case of sanctions lifting and lack of commitments by the Islamic Republic states for taking free and open economic policies, what would be the state of effective driving forces on the formation of virtual state? If so, which changes will be experienced by Iran's GPI?

- In the case of lack of sanctions lifting and commitments by the Islamic Republic states for taking free and open economic policies, how much it is possible for Iran to become a body virtual state by the outlook of 1404? If so, what would be the state of GPI?

- In the case of lack of sanctions lifting and lack of commitments by the Islamic Republic states for taking free and open economic policies, what would be the state of effective driving forces on the formation of virtual state by the outlook of 1404? If so, what would be the state of Iran's ranking in GPI? 
Based on the above questions and the goals of Delphi survey in this study, four technical panels have been considered. In each panel, ten administrative and academic authorities from the area of interest were selected whose compositions are as follows:

Table 1. The composition of Delphi survey panels' members

\begin{tabular}{|c|c|c|c|}
\hline Row & Panel name & Number & Scope \\
\hline 1 & Experts of economy and development & 10 & Faculty members, business managers \\
\hline 2 & $\begin{array}{l}\text { Experts of political science and international } \\
\text { relations }\end{array}$ & 10 & $\begin{array}{l}\text { Faculty members, member of parliament, } \\
\text { vice presidents of governmental planning } \\
\text { in the related fields }\end{array}$ \\
\hline 3 & Experts of information technology & 10 & $\begin{array}{l}\text { Elite graduates, managers of active } \\
\text { information technology in strategic } \\
\text { research institutes, experts of information } \\
\text { technology }\end{array}$ \\
\hline 4 & Experts of peace and militarism & 10 & $\begin{array}{l}\text { Peace researchers, militarism experts, } \\
\text { military commanders, senior executives in } \\
\text { the areas of defense and military }\end{array}$ \\
\hline
\end{tabular}

In this study, in order to stay committed to Delphi method and stay away from the criticism, purposive and snowball samplings were utilized. Therefore, a number of panel members were selected regarding personal awareness and information. In the areas in which there was no prior awareness, the authorities were asked to introduce experts and elites who are interested in the topic of study and have executive experience or knowledge in each of the four panels. Therefore, considering the probability of falling 35 to 70 percent in the first stage, the questionnaire was shared among 70 participants based on two methods of on-line and in-present. Finally, 40 participants were selected in this study in a way that there were 10 experts in each panel.

\section{Concepts and Theoretical Framework}

\subsection{Virtual State}

Speed and scale of globalization in today's world are unprecedented. Following the break and geographical distribution of production chain, the globalization process has made inextricable link with the global value chains. Also, regarding internationalization of service, the flow of foreign direct investment and service trade have obtained an increasing role in the scope of globalization. Value chain globalization depends on a large number of factors that the most important one is productivity. The most important tool for acquiring this goal is providing the resources from the most affordable domestic and international manufacturers, whether within the enterprise or out of its borders. The distribution of supply chain has largely affected enterprise's patterns in today's world, so that outsourcing and transferring capital to the functions (body enterprises) have led to one of their main functions and features (OECD, 2008: 7).This feature is the motif of virtual enterprises' formation that the virtual state has modeled it. The virtual enterprise is an interdisciplinary and ambiguous concept that various definitions have been proposed regarding it. As an example, NIIP project has described virtual enterprise as a consortium or temporary alliance of enterprises that have been gathered in order to share the costs and skills as well as utilizing the opportunities of rapidly changing market (Ulrich, 2001: 230). In fact, the virtual enterprises are a network of smaller enterprises and production lines that not only provide their required properties and resources from the inside of the enterprise or country, but provide them from the areas that have the highest productivity for them (Matos et al., 1998: 190).

Also, through modelling this concept, Richard Rosecrance in "No More State", while defining the concept of globalization as "an increasing motive of good production elements, workforce, capital and information among countries", believes that for providing raw materials, goods and capital, the states have relied on distant markets; therefore, they are increasingly relying on the economic forces that are not under their control. With tariff reductions, even the smaller state have gained more appropriate status in global arrangements. Those states with small national markets, can sell their goods abroad. But all these successes are highly dependent on the ability of states in attracting mobile capital or the so-called direct foreign investment (Rosecrance and Stein, 2006:4-8). In 
this regard, virtualization occurs based on the growth of capital and its flows in the global trade. Nowadays, direct foreign investment has increased much faster than Gross Domestic Product (GDP). This feature has presented the most unprecedented opportunities for economic process and peace (Rosecrance, 2008: 67).

According to the main purpose of Rosecrance by the virtual state, it is not the loss of state and authority, but is to decrease state's reliance following the evolutions of global economy. In fact, nowadays, three important elements in determining the growth and development of countries refer to capital, workforce and information. According to him, the human capital is much more important than raw materials, agriculture and oil. Therefore, if countries are able to develop their economy with an emphasis on human capital, have moved toward virtualization. The virtual state can be successful if be able to make trustable connections with the production institutes in other places. Therefore, it can replace the interdependence in production with the interdependence in trade. These lead to the growth of intangible service importance compared to tangible goods trade, either in international or regional levels. As a result, those states that move toward virtualization, must intensify these services and continue this trend. Finally, the national power depends on the education system and economic capability for implementing educated workforces (Rosecrance, 2008: 340-344).

Therefore, according to Rosecrance, the more the economies move toward services, the more they are virtual. Accordingly, virtual states such as Hong Kong, Swiss, Singapore, and Taiwan are more service-oriented than combined virtual states such as France, England and Germany and body virtual countries such as Malaysia, Indonesia and India are located at the end of this ranking. In fact, he believes that most of the developed economic systems have moved toward virtual states by the focus of management practices inside and outside the country, have not gone all the way (Rosecrance, 2008: 78).

He considers state's virtualization as a route toward achieving sustainable peace among communities, but does not determine its mechanism. Regarding peaceful international system, he writes: "if an international system wants the freedom of military conflicts between states, should make its best to keep states from participating in controversial activities or provide some resources by which states can acquire whatever they want, without any violence. But these techniques, in turn, are dependent on other factors: system structure and system interactions."

Rosecrance believes that regarding the main features of today's world wherein the interdependence makes conceptualization and understanding between countries so challenging, with systematic approach and at the same time, focusing on both domestic and foreign policies, it would become easier to describe the international system and find perfect solution for peace in the future (Rosecrance, 1981: 713). According to these theorists, the systematic liberal approach to increase economic interdependence, is one of the most important factors of decreasing war between states, since the states are highly interdependent and in the case of war, they will lose important advantages.

Before Rosecrance, several theorists, based on the framework of classic and systematic liberalism approach, considered trade and economic ties between states as a route to achieve peace. Angel (1910) claimed that expanding interconnected trade width, makes war as the great illusion (Schneider et al, 2013: 4). In his explanation, he points to two processes. First, modifying the nature of production, has made the subjugation of modern economies so costly and its management as profitable. The second process that Angel points out is the globalization of economy. According to him, the uniformity of global markets not only facilitates trade, but has created unfriendly benefits. Therefore, trade makes the war between great powers so costly, as far as makes it unacceptable in terms of rational (Herrera, 2012: 19). According to Rosecrance, the concept of interdependence as one of the main features of modern global dynamics that has converted the element of trade into the main peace factor at the present time, perhaps from the past centuries, various communities have been engaged in trade with each other. In terms of interdependence, the international system of states are increasingly dependent on other countries to provide military and economic necessities. Therefore, they have started trading and shared their responsibilities (Rosecrance, 1986: 14-15).

Therefore, in the period of state's virtualization, the international system moves toward a direction wherein the states have spent their power for developmental measures and since the production and distribution system of resources are structured in a modern way, it can be expected that without engaging in any violent conflict, the states can acquire whatever they want. Prior to this period, there were two reasons that the states were highly dependent on the element of territory. The first and most important reason is that states are a territorial organization and that's why uncontrolled expansion of a state can bring the attack of the state that that is responsible for that territory. Second, power as one of the governmental policy goals, is historically defined with territorial features (Rosecrance, 1986: 6-13). In fact, what has changed deeply, is the concept of power. In History and Neorealism, in addition to criticizing the neo-realist approach, he writes regarding international 
relations: "the rich concept of what has been called as power, is changing. It seems that great powers have changed their outlook from short-term to long-term, territorial goals to economic goals, tangible goals to intangible goals and extensive developmental strategies to compact models. On the other hand, normative developments have been occurred, too." He considers capital, workforce and technology as the main elements of power and believes that having such power inevitably leads to peace (May and Rosecrance, 2010: 8-13). In fact, virtualization is understanding this point that land area cannot overcome the economic problems. He defines virtual state in this way: "virtual state is a political unit that has minimized its land based on production capacity that is the logical result of liberation from the land. In general, virtual states and their partners prefer the global market rather than acquiring territories" (Rosecrance, 2008: 17).

However, it seems that what makes the mechanism to achieve peace as practical, is decreasing structural violence through increasing the level of trust between states; a trust that its conceptual context can be found in promoting social capital between networks that have been created through the relations between nations. Nowadays, various politicians in developed and developing countries believe that the development of economic ties benefits communities and decreases the danger of social conflicts. In 2003, World Trade Organization (WTO)introduced ten advantages of trading system that had been managing it and based on this document, the first advantage of international trading system is helping to promote peace in the world (WTO, 2003: 1). To explain the issue in better way, it is necessary to define peace at first place.

\subsection{The Definition of Peace, Distinguishing Positive and Negative Peace}

Peace, like happiness, harmony, justice and freedom is a concept that is often defined by its lack of sense. Therefore, John Gultung, the founder of peace studies, has introduced the main distinction between the concepts of positive and negative peace. The positive peace point to the simultaneous presence of many desirable mental and social aspects such as harmony, justice, fairness, etc. The negative peace has always been considered as the lack of war or other forms of conflicts. Most of the cultural, religious and philosophical traditions have applied the positive peace. In Webster's International Dictionary, peace in the first place is defined as getting rid of the confusions and civil unrest and has been positively defined as general relaxed state. Webster complements its explanations through providing the political or foreign meaning of positive peace, as security or order within the community that is provided by law, custom or public demand. Peace, also, points to creating harmony in human relations: as mutual agreement and trust, exactly like what we consider as the inter-personal or inter-subjective peace. Webster defines the word peas as the state of mutual agreement between states: lack of war or hatred. This conventional meaning of peace as the negative peace, has arisen from the terms of war freedom (Barash and Webel, 2014: 4).

John Gutlung as one of the founders of peace studies, considers peace studies as one of the branches of thought enlightenment period that more than anything, emphasizes peace, rights and, liberal peace. This branch of thought enlightenment, considers personal freedom as reflexing manners of mutual relationships that its advanced form leads to consistent peace and League of Nations. Also, he believes that common resources are formed as the general discourse (active civil society). Nowadays, in the days after war, the peace studies have entered their puberty and are highly ready for using the created opportunities in the modern period after the cold war; the period that its main features (i.e. the formation of global networks and international society) are highly interdependent (Miller, 2012: 9-11). Therefore, nowadays, we should look at peace from different point of view. In the world wherein increasing interdependence, the emergence of network relationships between states and transactional actors as well as adaptation of virtualization processes within states, are the prominent indicators and peace cannot be defined by the lack of war.

\subsection{The Virtualization of States in a System Based in Interdependence and Peace Promotion}

Generally, in international relations of peace, the concept of war absence is pointed out. When Aron, the French theorist in $20^{\text {th }}$ century, defined peace as "the state of more or less stable of competition between political units", indeed pointed to the concept of negative peace. His definition is the most common perception of peace within the framework of Political Science and International Relations and should relate this realist view that peace emerges in the absence of war or other organized violence to the mind. The opposite view of this realist view points to the concept of positive peace or social status in which exploitation has been minimized or is completely removed and there is no outright or structural violence. This state ensures fair social order and environmental harmony (Miller, 2012: 6-7). Indeed, Gutlung, for the first time points to other social aspects of peace. He attempted to propose more exact definitions of positive and negative peace. Therefore, he added personal violence and physical injuries to negative peace and related social injustice to the concept of positive peace. In this regard, he stated: "I'm aware of the changes that I arrived in the concepts of peace, while the concept of 
negative peace stays stable and the concept of positive peace is continuously changing. I consider peace as uniform states and cooperation, but now, I define it as social justice" (Martin, 2005: 46). As can be concluded form the above statements, Gutlung leaves the concept of peace almost intact. He has not pointed to the international environmental changes, events and processes that probably lead to the absence of war or negative peace among potential enemies in international system.

Kenneth Boulding has made distinction between positive peace and negative peace. He considers positive peace as a state based on competent management, regular settlements of conflicts, coordination with lasting relationships, gentleness as well as kindness and love and believes that negative peace points to the absence of violence such as chaos, conflict, tension, conflict and war. He also claims that war and peace, each with a collection of certain features, are definable states of a system. According to him, human activities are dividable into two general categories of disputed and non-disputed aspects. Non-disputed activities are peaceful but disputed behaviors can be divided based on the nature of other taboos into war and peace. This definition can be turned to the relations between states in international system wherein the absence of war does not necessarily mean peace, but conflict is the main nature of relations that possibly leads to war or violence. In fact, Boulding points to a state of international relations that the absence of war between two countries does not necessarily lead to relative peace among potential enemies (Martin, 2005: 47).

Rosecrance's view toward peace view is realistic. According to him, wars and conflicts are merely adjusted where virtualization has been occurred. In fact, the economic prosperity of a country is as much important as its military success in the past. In this condition, state employees have become economic ambassadors. In all virtual countries, the political state encourages the entry of aliens to simulate the economy in the country as well as create suitable economic opportunities. Therefore, the state can improve the standards of its people's life (Rosecrance, 2008, 99-130). Accordingly, the virtual state, through providing desirable condition in the country and promoting trust in its transnational network links, can improve the state of peace in the world. In the past two generations, the virtual states and those countries that were highly affected by virtualization, have gained unprecedented interest. Through initiating efficient production and economic advantages, these states have started investment and production with high volume. In their inside, they have turned to high degrees of study, design, investment and marketing (Rosecrance, 2008: 320). Therefore, for them, land and territory lose their importance that used to be very important. On the other hand, the historical progress of world economy indicates that those states that have relied on free and open economy, have more effective tools in acquiring resources compared to war state. Accordingly, in the modern period of production flows, they are more efficient compared to military flows. But, what are the examples of these concepts in practice?

Nowadays, according to the quantitative studies by the Institute for Economics and Peace of Sydney, it is easily possible to evaluate factors affecting the promotion of global peace quantitatively as well as their correlation with other indicators of positive and negative peace. Therefore, the significant framework to predict the future changes of PGI in countries is acquired. According to these finding, there is a significant relationship between the related factors of activating virtualization trends in countries. In general, it is possible to model the quantitative link of virtualization trends with GPI as follows:

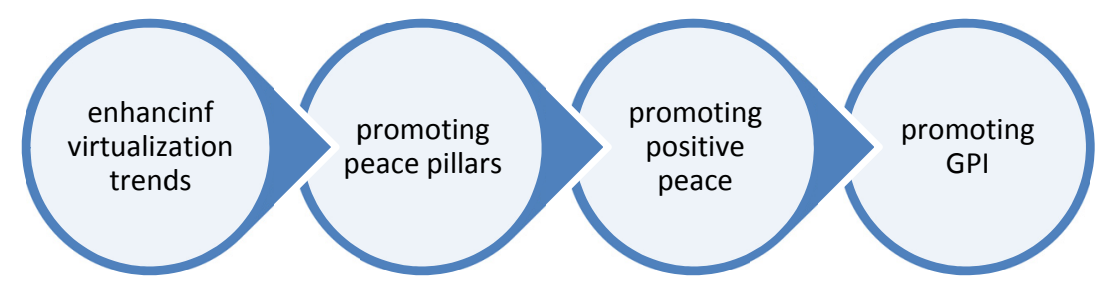

Figure 2. Quantitative link of virtualization trends with promoting GPI

For the approximate measurement of state's virtualization and their places on a spectrum presented by Rosecrance, it is not possible to utilize the general concepts of Rosecrance's vote regarding virtual state. In fact, in all future studies, the point for reference to the available theories about each subject under investigation, is clearly extracting the variables that have the ability for codification and prediction of variable's future. In the 
future studies process, these variables are considered as the driving or effective forces.

\section{The Driving Forces of Virtual State}

According to the conducted studies, seven driving forces have been considered for quantitative explanation and operationalizing the concept of virtual state including: Index of Economic Freedom, the share of service sector from GDP, the share of workforce working in service sector, direct foreign investment, the index of human capital, the index of business environment, ICT Development Index.

\section{The Driving Forces of Global Peace}

Despite concepts such as GDP or unemployment, it is not possible to measure peacefulness with a certain formula. GPI was the first step in operationalizing the concept of peace. GPI that was introduced by the Institute of Peace and Economics of Sydney in 2007, measured the levels of violence as well as the institutes and cultural and social views related to peace and presents trustable investigation of countries' peacefulness. This index, not only provides the possibility of ranking countries and comparing their peacefulness level for the researchers, but determines the factors that have significant correlation with the establishment of a peaceful society. This index consists of 21 quantitative and qualitative sub-indices that fall into three general categories. These categories consist of level of domestic safety and security, participation in domestic and international disputes, the level of militarism (Barash and Webel, 2014: 10-11). GPI can be linked to the concept of virtual state through defining the pillars of peace.

\subsection{The Pillars of Peace and Virtual State}

The pillars of peace are a new conceptual framework for understanding and describing factors affecting the establishment of a peaceful society. This framework defines the national features that are related to peace more than other factors and have been derived from a statistical analysis process. The pillars of peace are in fact among the few quantitative and comprehensive studies that have been conducted to determine and separate the positive effective factors to maintain and enhance a peaceful society. Attitudes, institutions and structures related to peace have been integrated with various aspects that are considered as desirable, such as strong business environment, gender equality and high levels of human capital. Therefore, the pillars of peace cannot explain the desirable environment for the emergence of peaceful potential features in human communities. The pillars of peace, provide a framework for evaluating positive peace factors that lead to the creation of a peaceful society. This classification, also, provides an ideal base to measure the peaceful potentials of communities. In establishing the pillars of peace, more than 900 indices, data collection and attitudes in relation to the driving forces of peace, flexibility and conflicts were analyzed in the current thinking. In order to ensure the development of a comprehensive framework, an interdisciplinary approach and simultaneous systematic approach were used in the application of peace concept. Finally, the pillars of peace are dividable into the following 8 branches: a state with good performance, perfect business environment, equitable distribution of resources, acceptance of the rights of others, good relations with neighbors, free flow of information, high levels of human capital, and low levels of corruption.

These eight elements are completely related to the establishment of a peaceful environment. On the other hand, they boost each other mutually, in a way that the improvement and promotion of an element relates to other elements and vice versa. For example, the good performance of a state, the business environment and free flow of information are effective on decreasing the level of corruption. Also, the low level of corruption affects financial transparency; therefore, they will affect the business environment, the performance of state and people's capabilities regarding participation in corruption. Accordingly, due to the mutual continuity of these elements regarding each other, their weakness or strength can be related to the weakness and strength of other elements (IEP, 2011: 3-10). Can states, merely with reliance on activating virtualization trends, promote their rank on the annual GPI? In 2013, the Institute for Economics and Peace of Sydney in its annual report, devoted a section to Positive Peace Index (PPI). Therefore, 126 countries in 24 sub-indices were investigated. The final results indicated that the mean of positive peace between 2010 and 2015 was promoted by 1.7 percent. According to these findings, the state of global positive peace has been developed in equitable distribution of resources, the level of human capital, free flow of information, the level of corruption, acceptance of others' rights and good governance by the state. The Institute for Economics and Peace of Sydney has developed PPI for countries' ranking based on the level of their development in attitudes, institutes and desirable structure to protect the stable peace, create flexibility and developing human potential. Accordingly, it would be possible to evaluate the levels of deficit and surplus of a country. If the PPI ranking of a country is significantly lower than GPI ranking, it means that that country will encounter significant fall in the peace index. Recent experiences about those countries that have higher rates of fall in the ranking of GPI indicate deficit of these countries in peace index. 
Also, the Institute for Economics and Peace of Sydney has found that there is a little relationship between negative peace and factors relating to PPI. Therefore, it is possible to evaluate the levels of deficit and surplus of a country regarding the peace index. If the PPI ranking of a country is significantly lower than its GPI ranking, it means that that country will encounter significant fall in the peace index. Recent experiences about those countries that have higher rates of fall in the ranking of GPI indicate deficit of these countries in peace index. Those countries that encounter Arab spring had high levels of deficits in peace index (IEP, 2011: 1-3). Both positive and negative peace are producer and product of a form of trust and coherence that this constitutes the most important prerequisite for having a prosperous community with good performance. However, those countries that higher peace index, have enjoy from better quality regarding other socioeconomic aspects. The findings indicate that countries with higher PPI rating have more income, more equitable distribution of resources, better education and health outcomes, promoting trust between citizens, and more social cohesion (IEP, 2013: 81). Statistical studies indicate that both three sub-index of GPI are correlated with eight elements of peace, although some of these sub-indices are stronger than others. For example, the weakest relationship exists between peace elements and militarism, while the strongest one can be found between security sub-index and community safety and the peace elements.

Table 2. The correlation of peace elements with three sub-indices of GPI (source: Institute for Economics and Peace of Sydney)

\begin{tabular}{|c|c|c|c|c|c|c|c|c|c|}
\hline Sub-index & $\begin{array}{c}\text { General } \\
\text { correlation }\end{array}$ & $\begin{array}{l}\text { State's good } \\
\text { performance }\end{array}$ & $\begin{array}{c}\text { Suitable } \\
\text { business } \\
\text { environment }\end{array}$ & $\begin{array}{l}\text { Low level } \\
\text { of } \\
\text { corruption }\end{array}$ & $\begin{array}{c}\text { High } \\
\text { level } \\
\text { of } \\
\text { human } \\
\text { capital }\end{array}$ & $\begin{array}{c}\text { Accepting } \\
\text { others' } \\
\text { rights }\end{array}$ & $\begin{array}{c}\text { Equitable } \\
\text { distribution } \\
\text { of } \\
\text { resources }\end{array}$ & $\begin{array}{c}\text { Good } \\
\text { elationship } \\
\text { with } \\
\text { neighbors }\end{array}$ & $\begin{array}{l}\text { Free flow } \\
\text { of } \\
\text { information }\end{array}$ \\
\hline $\begin{array}{l}\text { Domestic } \\
\text { and } \\
\text { international } \\
\text { conflicts }\end{array}$ & 0.562 & 0.458 & 0383 & 0.555 & 0.356 & 0.509 & 0.300 & 0.630 & 0.507 \\
\hline Militarism & 0.329 & 0.248 & 0.228 & 0.321 & 0.181 & 0.382 & 0.184 & 0.415 & 0.384 \\
\hline $\begin{array}{c}\text { Social } \\
\text { safety and } \\
\text { security }\end{array}$ & 0.857 & 0.856 & 0.757 & 0.858 & 0.730 & 0.754 & 0.639 & 0.760 & 0.693 \\
\hline
\end{tabular}

As can be seen from the above table, it can be said that the most significant statistical relationship is the weak correlation between militarism and the level of human capital and equitable distribution of resources. Therefore, those virtual states that spent most of their commitment for human capital, especially areas of training and development of related infrastructure such as information technologies, strengthen two main elements of peace and will devote less attention to militarism as well as increasing power. Also, since there is a positive relationship between militarism and relations with neighbors, through decreasing the militarism degree it will be possible to strengthen another elements of peace that is relationships with neighbors. On the other hand, all elements of peace are highly correlated with the sub-index of social security and safety. The highest correlation can be found between the level of corruption and increased social security and safety. Although it is difficult to speak definitively about the relationship between cause and effect, regression analysis indicates that governance, corruption and business environment have the highest effects on the level of social safety and security. Therefore, in the virtual states where in the commitments concentrate on the promotion of functions such as providing suitable business environment, promotion of human capital and taking open economic policies, can affect the social security and safety sub-index of GPI in a positive way. In the sub-index of domestic and international conflicts, the highest correlation exists between the levels of corruption.

In fact, virtual states, through desirable performance in open economic policies that consist of freedom from corruption and regulatory efficiency, are very successful in decreasing the level of corruption. On the other hand, 
as was pointed out, the level of corruption has a strong relationship with the element of state's desirable performance and information free flow. Therefore, through developing information technologies that constitute the main element of improving free information flow, the virtual states will have desirable performance in promoting the most important elements relating to the level of corruption. Therefore, virtual states, in third sub-branch of GPI (i.e. participation in domestic and international conflicts), are generally in good state. As was mentioned, the findings indicate the interdependence of peace elements with PPI as well as GPI. On the other hand, the elements of peace are somehow related to the functions of virtual state, is such a way in which it can be concluded that with through activating the virtualization trends in states, the elements of peace will be enhanced and this will help the promotion of positive peace indices and finally GPI.

Table 3. The trend of GPI in Iran

\begin{tabular}{|c|c|c|c|c|c|c|c|}
\hline Iran & 2008 & 2009 & 2010 & 2011 & 2012 & 2013 & 2014 \\
\hline Total rating & 2.456 & 2.241 & 2.341 & 2.2 .438 & 2.417 & 2.437 & 2.437 \\
\hline Rank & $\begin{array}{l}121 \\
\text { out of } \\
138\end{array}$ & $\begin{array}{l}106 \text { out of } \\
143\end{array}$ & $\begin{array}{l}119 \text { out of } \\
148\end{array}$ & $\begin{array}{l}127 \text { out of } \\
153\end{array}$ & $\begin{array}{l}132 \text { out of } \\
158\end{array}$ & 137 & $\begin{array}{l}131 \text { out of } \\
162\end{array}$ \\
\hline Militarism & 2.2 & 2 & 2.1 & 1.9 & 2 & 2.1 & 2.1 out of 5 \\
\hline
\end{tabular}

Theoretically, as Bounding points, through establishing the virtualization trends, a growing network of international non-governmental and individuals will be created that its main purposes consist of international understanding, peace and security for the whole world, not only for a group of specific people. Virtual states deal with the more transnational concepts of security (Hurrell, 2007: 100). In fact, for the first time in history, we deal with this realistic possibility to end the great wars between advanced states. In global development, we have reached a point that gradually understand that the real greatness of communities will be evaluated based on the quality of social and economic relations, not through looking at military resources under their command (Miller, 1990: 251).

\subsection{Analyzing the Quantitative Trends in Virtualization Indices in Iran}

In this study, it has been attempted to investigate Iran's status in each deriving force of states' virtualization referring to the information and available documents that due to the extent of data available here, only four final scenarios will be considered that have been written based on the analysis for existing data trends.

\section{Codification of Final Scenarios}

In investigating three general deriving forces of virtual state formation, we found that the way in front of Iran to achieve each of the three states of virtual state until to outlook of 1404 (), is faced by two basic uncertainty: sanctions removal or vice versa; following open economic policies by the state.

According to the researchers and observers of international trends, sanctions are one of the main obstacles for Iran in achieving the intended outlooks. These deriving forces have negative effects on economic growth, attracting foreign capitals, state's ability to gain the trust of investors, promoting the business environment, promoting human capital and developing the infrastructures of information technology. Without sanctions removal, it will not be possible to surpass the threshold growth rate of 5 percent. From the theoretical view, the main prerequisite for the formation of a virtual state in any country is attracting an acceptable level of international trust; since the investors generally transfer their capitals to the locations wherein there is minimal political, economic and environmental risks. Therefore, due to the continuity of sanctions, it would be difficult to achieve the initial assumption.

In addition to international sanctions, another deriving force that there is uncertainty regarding it, is to commitments of Iran's states in the pursuit of open economic policies. During the 19 years that Iran's status regarding economic freedom has been evaluated by the Heritage Foundation, this country has only about 4 growth points. Now, Iran has the lowest ranking in the Middle East that is within the area of the outlook. The largest increase in rankings regarding the index of economic freedom was seen between 2002 and 2005, during which, the state made lasting commitment to pursuit and implement the policies of free economy. Therefore, one of the effective elements in predicting future events regarding the formation of virtual state in Iran, is state's commitment to pursuit the open and free economic policies. This is especially important since the general trend 
of the global average of the economic freedom is increasing and this trend will continue until 2025.

According to what happened, the space of Iran's scenarios about the formation of virtual state in Iran by the outlook of 1404 and its effect on the promotion of GPI will be as follows.

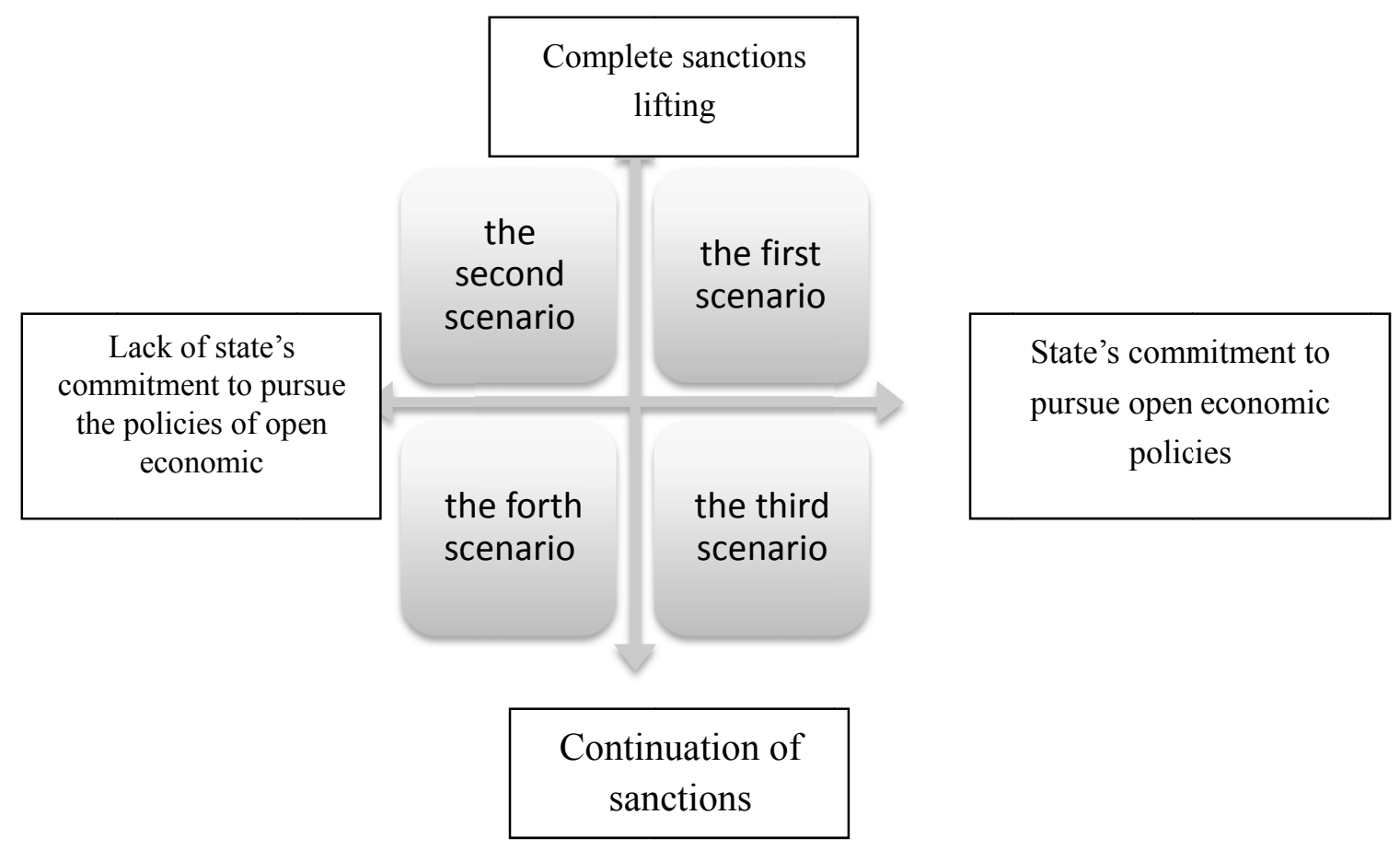

5.1 The First Scenario: The Virtual State by the Outlook of 1404-Additional Positive Peace, Promotion of Negative Peace

In this scenario, the followings are probable:

$\checkmark$ Achieving the economic growth over 8 percent

$\checkmark$ Promoting the economic freedom index until the global average level

$\checkmark$ To become one of the main destinations for direct foreign investments in the region

$\checkmark$ Developing human capital and becoming the top country in the region for starting business

$\checkmark$ Desirable business environment in Iran to attract advanced workforce and the entrance of economic firms

$\checkmark$ To become one of the most developed countries in the region under the index of expertise and the use of information technology

$\checkmark \quad$ To become one of the main destinations for high tech investments

$\checkmark$ Therefore, the state of GPI in negative peace indices related to sub-indices of militarism and domestic as well as international conflicts improves and by the outlook of 1404, Iran will experience significant rise in the ranking of global peace

5.2 The Second Scenario: The Continuation of Reliance on Tangible Resources, Positive Peace Deficit, Promotion of Negative Peace

In this scenario, the followings are probable:

$\checkmark$ Achieving the economic growth over 8 percent

$\checkmark$ Promoting the economic freedom index until the global average level

$\checkmark$ To become one of the main destinations for direct foreign investments in the region

$\checkmark$ Developing human capital and becoming the top country in the region for starting business

$\checkmark$ Desirable business environment in Iran to attract advanced workforce and the entrance of economic firms 
To become one of the most developed countries in the region under the index of expertise and the use of information technology

$\checkmark \quad$ To become one of the main destinations for high tech investments

$\checkmark \quad$ Until the outlook of 1404, Iran's state will be improved under the indices of militarism and engagement in domestic and international conflicts more than the level of domestic security and safety.

$\checkmark$ Accordingly, until the outlook of 1404, Iran will experience deficit in peace index as well as significant fall in GPI.

5.3 The Third Scenario: Body Virtual State in Additional Positive Peace and the Stability of Negative Peace

$\checkmark$ Achieving the economic growth between 5-8 percent

$\checkmark$ Approaching Iran's economic freedom index to the global average

$\checkmark$ Conducting foreign investments to service sections

$\checkmark$ Desirable business environment until the average level of the region

$\checkmark$ Promoting investments in human capital

$\checkmark$ Becoming one of the most developed countries in the region under the index of information technology growth

$\checkmark$ To become one of the main destinations for high tech investments

$\checkmark$ Activating virtualization trends and promoting the elements related to positive peace has led to additional positive peace and in the years to come, will experience good rise in GPI ranking

5.4 The Fourth Scenario: The State of a Backward Country, the Fall of Positive Peace Index and Far Worse Situation for Negative Peace

$\checkmark \quad$ The economic growth will be lower than 5 percent

$\checkmark$ The index of economic freedom in Iran will continue its downtrend

$\checkmark$ The size of foreign investment will be minimized

$\checkmark$ The situation of nosiness in Iran will be undesirable

$\checkmark$ Investments on human capital will not grow

$\checkmark \quad$ Iran will become an importer of goods and services related to information technology

$\checkmark \quad$ Iran still will rely on tangible power sources

$\checkmark \quad$ In addition to the fall of positive peace, Iran will face intense fall in sub-indices of militarism and domestic as well as international conflicts that are correlated with negative peace. On the other hand, the difference between PPI and GPI will remain unchanged and Iran will experience significant reduction in GPI

\section{The Findings of Analytical Surveys}

\subsection{Analyzing the Results of the First Round Delphi}

In this study, the data of sample were uniformed and classified using statistics and SPSS software. Then, these data are analyzed and interpreted.

\section{The demographic features of demographic variables}


Table 4. The demographic features related to the demographic variable of age

\begin{tabular}{rrrrrr}
\hline \multicolumn{5}{c}{ Age } \\
\hline Sample & Ender 30 & 1 & 2.5 & 2.5 & 2.5 \\
& Unency & Percentage & Sample percentage & Cumulative frequency \\
& 30 to 40 & 8 & 20.0 & 20.0 & 22.5 \\
& 40 to 50 & 11 & 27.5 & 27.5 & 50.0 \\
& Above 50 & 20 & 50.0 & 50.0 & 100.0 \\
& Total & 40 & 100.0 & 100.0 & \\
\hline
\end{tabular}

Although the reliability and validity in Delphi surveys are not accurate, it has been attempted to obtain acceptable reliability through optimizing questions.

Table 5. Cronbach's alpha regarding expressing reliability and validity of the questionnaire

\begin{tabular}{cc}
\hline Cronbach's alpha & Number of items \\
\hline 0.761 & 36 \\
\hline
\end{tabular}

According to the Cronbach's alpha test, we see that the alpha is higher than 70 percent. Therefore, this questionnaire enjoys from good reliability.

Hypothesis 1: there is a significant difference between Scenario $A$ and average reference

Hypothesis 2: there is a significant difference between Scenario $B$ and average reference

Hypothesis 3: there is a significant difference between Scenario $C$ and average reference

Hypothesis 4: there is a significant difference between Scenario $D$ and average reference

\section{Scenario A:}

According to Kolmogorov-Smirnov test, with the result of 0.873 , the variables at the error level of less than 5 percent enjoy from high normality. This means that the significance level of this test is higher than 5 percent.

\section{Hypothesis 1:}

Table 6. The statistical features of Scenario A

\begin{tabular}{rrr}
\hline \multicolumn{2}{c}{ Statistical features } \\
\hline & Scenario A & \\
\hline & Mean & 40 \\
\hline & SD & 0 \\
\cline { 2 - 4 } & mean & 2.5833 \\
median & mode & 2.4444 \\
SD & 2.00 \\
variance & .89660 \\
variation range & .804 \\
Minimum & 5.11 \\
maximum & 1.00 \\
total & 6.11 \\
& & 103.33 \\
\hline
\end{tabular}


Examining hypothesis 1: there is a significant relationship between Scenario $A$ and average reference.

T-test for expressing significance and non-significance of mean difference between average reference and Scenario A.

Table 7. Univariate t-test

\begin{tabular}{|c|c|c|c|c|c|c|c|}
\hline \multicolumn{8}{|c|}{ Univariate t-test } \\
\hline & \multicolumn{7}{|c|}{ The base value $=3$} \\
\hline & \multirow{3}{*}{$\mathrm{t}$} & \multirow{3}{*}{$\begin{array}{l}\text { Degree } \\
\text { freedom }\end{array}$} & \multirow{3}{*}{ of } & \multirow{3}{*}{ Significance level } & \multirow{3}{*}{ Mean difference } & \multicolumn{2}{|c|}{ Confidence level of $95 \%$} \\
\hline & & & & & & Lower & Upper \\
\hline & & & & & & limit & limit \\
\hline Scenario A & -2.939 & 39 & & .006 & -.41667 & -.7034 & -.1299 \\
\hline
\end{tabular}

Due to the reverse scoring in this questionnaire, the lower ranking mean indicates high closeness to the option. According to the table above, we see that lower and upper limits are on one side of zero. Therefore, there is a significant difference between average reference and Scenario A. In order to express significance or non-significance of this difference, we use the significance level of t-test. According to the univariate $t$-test as well as the above table, we observe that at the error level of less than 5 percent, the significance level of t-test $(0.006)$ has become less than 5 percent that indicates there is a significant difference between average reference and Scenario A (negative mean difference $=0.41667$ ). Therefore, $\mathrm{HO}$ is rejected and $\mathrm{H} 1$ is confirmed. The standard deviation (SD) of 0.89 for the first scenario indicates the consensus of experts regarding the items related to this scenario.

\section{Hypothesis 2:}

Scenario B: In sanctions lifting condition and the lack of commitment by Iranian state to pursue free and open economic policies

\section{Descriptive features of Scenario B}

In the following table, we can observe statistical features such as mean, median, mode, $\mathrm{SD}$, variance, range related to Scenario B.

Table 8. Statistical feature related to Scenario B

\begin{tabular}{ccc}
\hline & Statistical features & \\
\hline & & Scenario B \\
\hline \multirow{2}{*}{ Sample } & 40 \\
\cline { 2 - 3 } & Lost data & 0 \\
\hline mean & 2.7556 \\
median & 2.6667 \\
mode & 2.67 \\
SD & .60083 \\
variance & .361 \\
variation range & 2.78 \\
minimum & 1.00 \\
maximum & 3.78 \\
total & 110.22 \\
\hline
\end{tabular}

Examining hypothesis 2: there is a significant relationship between Scenario B and average reference.

According to Kolmogorov-Smirnov test with the result of 0.539 , the variables are at the error of less than 5 
percent with high levels of normality. This means that the significance level of this test is higher than 5 .

T-test, for expressing the meaningfulness or non-meaningfulness of mean difference between average reference and Scenario B.

Table 9. Univariate t-test

\begin{tabular}{|c|c|c|c|c|c|c|}
\hline \multicolumn{7}{|c|}{ Univariate t-test } \\
\hline & \multicolumn{6}{|c|}{ The base value $=3$} \\
\hline & \multirow[t]{2}{*}{$\mathrm{t}$} & \multirow{2}{*}{$\begin{array}{l}\text { Degree of } \\
\text { freedom }\end{array}$} & \multirow{2}{*}{$\begin{array}{c}\text { Significance } \\
\text { level } \\
\end{array}$} & \multirow{2}{*}{$\begin{array}{c}\text { Mean } \\
\text { difference }\end{array}$} & \multicolumn{2}{|c|}{ Confidence level of $95 \%$} \\
\hline & & & & & Lower limit & Upper limit \\
\hline Scenario A & -2.573 & 39 & .014 & -.24444 & -.4366 & -.0523 \\
\hline
\end{tabular}

Due to the reverse scoring in this questionnaire, the lower ranking mean indicates high closeness to the option. According to the table above, we see that lower and upper limits are on one side of zero. Therefore, there is a significant difference between average reference and Scenario B. In order to express significance or non-significance of this difference, we use the significance level of t-test. According to the univariate $t$-test as well as the above table, we observe that at the error level of less than 5 percent, the significance level of t-test $(0.014)$ has become less than 5 percent that indicates there is a significant difference between average reference and Scenario B (negative mean difference $=0.24444$ ). Therefore, H0 is rejected and H1 is confirmed. The standard deviation (SD) of 0.06 for the second scenario indicates significant difference between the attitudes of experts regarding the items related to this scenario.

\section{Hypothesis 3:}

Scenario C: In sanctions lifting condition and the lack of commitment by Iranian state to pursue free and open economic policies

\section{Descriptive features of Scenario $C$}

In the following table, we can observe statistical features such as mean, median, mode, $\mathrm{SD}$, variance, range related to Scenario C.

Table 10. Statistical feature related to Scenario C

\begin{tabular}{ccc}
\hline & Statistical features & \\
\hline & & Scenario C \\
\hline \multirow{2}{*}{ Sample } & 40 \\
\cline { 2 - 3 } & Lost data & 0 \\
\hline median & 2.9778 \\
mode & 3.0000 \\
SD & 2.22 \\
variance & .57828 \\
variation range & .334 \\
minimum & 2.00 \\
maximum & 2.11 \\
total & 4.11 \\
\end{tabular}

According to Kolmogorov-Smirnov test with the result of 0.770 , the variables are at the error of less than 5 percent with high levels of normality. This means that the significance level of this test is higher than 5 . 


\section{Examining hypothesis 3: there is a significant relationship between Scenario $\mathrm{C}$ and average reference.}

T-test, for expressing the meaningfulness or non-meaningfulness of mean difference between average reference and Scenario C.

Table 11. Univariate t-test

\begin{tabular}{ccccccr}
\hline \multicolumn{7}{c}{ Univariate t-test } \\
\hline & $\mathrm{t}$ & $\begin{array}{c}\text { Degree of } \\
\text { freedom }\end{array}$ & \multicolumn{2}{c}{$\begin{array}{c}\text { Significance } \\
\text { level }\end{array}$} & $\begin{array}{c}\text { Mean } \\
\text { difference }\end{array}$ & \multicolumn{2}{c}{ Confidence level of 95\% } \\
\cline { 2 - 7 } & & 39 & .809 & -.02222 & -.2072 & .1627 \\
\hline Scenario C & -.243 & & & & Lower limit & Upper limit \\
\hline
\end{tabular}

Due to the reverse scoring in this questionnaire, the lower ranking mean indicates high closeness to the option.

According to the table above, we see that lower and upper limits are not on one side of zero. Therefore, there is not any significant difference between average reference and Scenario C. In order to express significance or non-significance of this difference, we use the significance level of t-test. According to the univariate t-test as well as the above table, we observe that at the error level of less than 5 percent, the significance level of t-test $(0.809)$ has not become less than 5 percent that indicates there is not any significant difference between average reference and Scenario C (negative mean difference = -.02222). Therefore, H0 is confirmed and H1 is rejected. The standard deviation (SD) of 0.57 for this scenario indicates the disagreement of experts regarding the items related to this scenario. In fact, 6 items out of 9 items of this scenario were not agreed by the experts.

\section{Hypothesis 4:}

Scenario D: In sanctions lifting condition and the lack of commitment by Iranian state to pursue free and open economic policies

\section{Descriptive features of Scenario D}

In the following table, we can observe statistical features such as mean, median, mode, $\mathrm{SD}$, variance, range related to Scenario D.

Table 12. Statistical feature related to Scenario D

\begin{tabular}{ccc}
\hline & Statistical features & \\
\hline & & Scenario C \\
\hline \multirow{2}{*}{ Sample } & 40 \\
\cline { 2 - 3 } & Lost data & 0 \\
\hline mean & 2.2889 \\
median & 2.1667 \\
mode & 2.00 \\
SD & .82414 \\
variance & .679 \\
variation range & 5.11 \\
minimum & 1.11 \\
maximum & 6.22 \\
total & 91.56 \\
\hline
\end{tabular}

Examining hypothesis 4: there is a significant relationship between Scenario $D$ and average reference.

According to Kolmogorov-Smirnov test with the result of 1.153, the variables are at the error level of less than 5 percent with high levels of normality. This means that the significance level of this test is higher than 5 . 
T-test, for expressing the meaningfulness or non-meaningfulness of mean difference between average reference and Scenario D.

Table 13. Univariate t-test

\begin{tabular}{|c|c|c|c|c|c|c|}
\hline \multicolumn{7}{|c|}{ Univariate t-test } \\
\hline & \multicolumn{6}{|c|}{ The base value $=3$} \\
\hline & \multirow[t]{2}{*}{$\mathrm{t}$} & \multirow{2}{*}{$\begin{array}{l}\text { Degree of } \\
\text { freedom }\end{array}$} & \multirow{2}{*}{$\begin{array}{c}\text { Significance } \\
\text { level }\end{array}$} & \multirow{2}{*}{$\begin{array}{c}\text { Mean } \\
\text { difference }\end{array}$} & \multicolumn{2}{|c|}{ Confidence level of $95 \%$} \\
\hline & & & & & Lower limit & Upper limit \\
\hline Scenario D & -5.457 & 39 & .000 & -.71111 & -.9747 & -.4475 \\
\hline
\end{tabular}

Due to the reverse scoring in this questionnaire, the lower ranking mean indicates high closeness to the option.

According to the table above, we see that lower and upper limits are on one side of zero. Therefore, there is a significant difference between average reference and Scenario D. In order to express significance or non-significance of this difference, we use the significance level of t-test. According to the univariate t-test as well as the above table, we observe that at the error level of less than 5 percent, the significance level of t-test $(0.809)$ has become less than 5 percent that indicates there is a significant difference between average reference and Scenario D (negative mean difference $=-.71111$ ). Therefore, H0 is confirmed and H1 is rejected. This scenario with the SD of 0.82 is the most desirable scenario of the first round Delphi among the experts and almost in all items of this scenario, the consensus of above 60 percent was resulted.

Table 14. Freidman test to rank each of the variables

\begin{tabular}{lc}
\hline & Ranking \\
\hline & Ranking mean \\
\hline Scenario A & 2.29 \\
Scenario B & 2.91 \\
Scenario C & 3.13 \\
Scenario D & 1.68 \\
\hline
\end{tabular}

Due to the reverse scoring in this questionnaire, the lower ranking mean indicates high closeness to the option.

According to the above table, we observe that Scenario D and Scenario C have the highest and most desirable variables, respectively.

Table 15. The error level of Freidman test

\begin{tabular}{lr}
\hline & Freidman test \\
\hline Frequency & 40 \\
Chi-square & 31.588 \\
Degree of freedom & 3 \\
Significance level & .000 \\
\hline
\end{tabular}

According to Freidman test as well as the above table, we observe that at the error level of below 5 percent, there is a significant difference between variables regarding their ranking status.

\section{Designing the questions of second round of Delphi and the feedbacks}

In the second round of this survey and based on the obtained data from analyzing the first round questionnaires, to achieve the consensus and design the second round questions, those items which were accompanied by more than 60 percent consensus were removed and the second round questions were designed. In this round, to achieve the consensus, designing five-item questions were banned and the respondents had to merely express 
their opinion regarding the vote of other panel members. Therefore, in front of each item, the percentages of agreement or disagreement of experts in the first round were appeared. Also, in order to enhance the quality of analytical-survey as well as enumerating closer view and attitude, in addition to expressing their agreement or disagreement, the experts were asked to state their reasons regarding continuation of their comments. It is worth mentioning that from 40 participants in the first round of Delphi survey, 4 participants withdrew from the second round. Therefore, the second round of Delphi was performed with the presence of 36 experts. According to the findings of this round (results are reserved by the researcher), the levels of desirability and possibility of each scenarios are evaluated. Accordingly, presenting the details of questionnaire, the responses of experts, and statistical analyses are avoided due to their details and only summary and conclusions are presented.

\section{Conclusion}

According to the consensus-building process of the second round of Delphi, it is possible to introduce Scenario $\mathrm{D}$ as the most probable and scenario $\mathrm{A}$ as the most desirable ones. This means that in the case of sanctions lifting and state's commitment to pursue open economic policies, Iran will return to combined virtual state and we can hope that in this condition, the structural violence in society decreases and we will face additional positive peace and promotion of GPI by the outlook of 1404. At the same time, Scenario D is the most probable one from the experts' point of view. Therefore, in the case of sanctions lifting and the lack of commitment by the state to pursue open and free economic policies, we should expect the fall of Iran in the ranking of GPI by the outlook of 1404. Two scenarios of B and C are the alternative scenarios for A and B. according to the Delphi survey in this study, the highest disagreement exists regarding Scenario C. In the case of sanctions continuation, the elites of politics, economy, peace, and information technology believe that Iran will progress in deriving forces of virtual state and following that, they were uncertain regarding the promotion of GPI in the future. In Scenario B, there is a significant disagreement in experts' views regarding the available items in the questionnaire. In means that, in the case of sanctions lifting and the lack of commitment by state to pursue open and free economic policies, still it's not possible to be optimistic regarding the progress of key deriving forces of virtual condition formation and following that, the promotion of GPI.

Therefore, it can be concluded that since two elements of sanctions lifting and state's commitment to pursue open and free economic policies are parallel and next to each other, it is possible to be optimistic about future. According to the obtained data in this study, it can be concluded that even in the case of sanctions lifting, if the states have not taken appropriate policies to promote the index of economic freedom of the Islamic Republic of Iran's state, it is not possible to be optimistic about the progress of deriving forces of virtual state as well as the promotion of GPI. As was mentioned at the beginning of this study, the economic development and peace are interdependent. Economic development will bring sustainable peace and without its promotion, the state of Iran in GPI ranking will not be promoted and it's not possible to be optimistic to promote the state of economic development in the Islamic Republic of Iran.

\section{References}

Andrew, H. (2007). On Global Order, Power and Value. New York:Oxford University Press.

Barash David, P., \& Webel Charles, P. (2014). Peace and Conflict Studies (3rd ed.). Washington DC: SAGE.

Camarinha-Matos, L. M., Afsarmanesh, H., Garita, C., \& Lima, C. (1998). Towards an architecture for virtual $\begin{array}{llll}\text { enterprises. Journal of intelligent } & \text { Manufacturing, } & 9(2), & 189-199 .\end{array}$ http://dx.doi.org/10.1023/A:1008880215595

Franke, U. J. (Ed.). (2001). Managing Virtual Web Organizations in the 21st Century: Issues and Challenges: Issues and Challenges. IGI Global.

Franke, U. J. (Ed.). (2001). Managing Virtual Web Organizations in the 21st Century: Issues and Challenges: Issues and Challenges. IGI Global.

Herrera Geoffrey, L. (2012). Technology and international Transformation. New York:Sunny Press.

Institute for Economics and Peace. (2013). Global Peace index 2013. Retrieved from http://economicsandpeace.org/publications

Institute for Economics and Peace. Global Peace Index 2014.

May, E. R., Rosecrance, R., \& Steiner, Z. (Eds.). (2010). History and neorealism. Cambridge University Press. http://dx.doi.org/10.1017/CBO9780511778551

Miller Lynn, H. (1990). Global Order: Values and Power in International Politics (2nd ed.). Boulderco: Westiview Press. 
OECD. (2008). Staying Competiveness in Global Economy. OECD P7.

Rosecrance Richard, N., \& Stein Arthur, A. (2006). No More State? New York: Rowman and Littlefield.

Rosecrance, R. (1981). Reward, punishment, and interdependence. Journal of Conflict Resolution, 25(1), 31-46. http://dx.doi.org/10.1177/002200278102500102

Rosecrance, R. N. (1973). International relations: peace or war? McGraw-Hill Companies.

Rosecrance, R. N. (1986). The rise of the trading state: Commerce and conquest in the modern world (Vol. 386). New York: Basic Books.

Rosecrance, R. N. (1999). The rise of the virtual state: Wealth and power in the coming century. Basic Books.

Rosecrance, R. N., Solingen, E., \& Stein, A. A. (2006). Globalization and Its Effects: Introduction and Overview. No More States, 3-4.

Snyder Quddus, Z. (2013). The liberal trading state: liberal systemic theory and the mechanism of socialization. journal of peace research, 50(33).

The 20-year Outlook. Retrieved from http://www.parliran.ir/?siteid=1\&pageid=220

The Institute for Economics and Peace. (2012). Pillars of Peace. Retrieved from http://economicsandpeace.org/wp-content/uploads/2011/10/Pillars-of-Peace-Report-IEP.pdf

The Institute for Economics and Peace. (2013). Global Peace Index 2013. Retrieved from http://economicsandpeace.org

The Institute for Economics and Peace. (2014). Global Peace Index 2014. Retrieved from http://economicsandpeace.org/

WTO. (2003). 10 Benefits of WTO Trading System. Retrieved from http://www.wto.org/english/res_e/doload_e/10b_e.pdf

\section{Copyrights}

Copyright for this article is retained by the author(s), with first publication rights granted to the journal.

This is an open-access article distributed under the terms and conditions of the Creative Commons Attribution license (http://creativecommons.org/licenses/by/3.0/). 